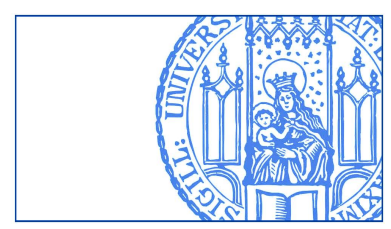

Stoegbauer, Christian und Komlos, John:

Averting the Nazi Seizure of Power

Munich Discussion Paper No. 2004-3

Department of Economics

University of Munich

Volkswirtschaftliche Fakultät

Ludwig-Maximilians-Universität München

Online at https://doi.org/10.5282/ubm/epub.305 


\title{
Averting the Nazi Seizure of Power: A Counterfactual Thought Experiment ${ }^{1}$
}

\author{
Christian Stögbauer and John Komlos \\ Department of Economics, University of Munich
}

Corresponding author: John Komlos, Department of Economics, University of Munich, Ludwigstraße 33/IV, D-80539 Munich, Germany, email: jk@econhist.de

Telephone: +49-89-2180-5824; Voice Mail: +49-89-2180-3169; Fax: +49-89-33-92-33

\begin{abstract}
The Great Depression in Germany led to the radicalization of the electorate, leading the country and then the world into the darkest days of Western Civilization. Could it have been otherwise? This paper explores whether the NSDAP takeover might have been averted with a fiscal policy that lowered the unemployment rate in those parts of Germany where their support rose most rapidly. A counterfactual simulation model based on estimates of the relationship between unemployment and the radical vote at the electoral district level provides a framework for considering how much lower unemployment would have to have been in those districts to prevent the NSDAP from becoming a formidable political force in Germany. Budget neutrality is maintained, so that the simulations do not depend on an expanded fiscal policy. The results indicate that such a policy could well have averted the NSDAP's seizure of power, and the catastrophe that followed in its wake.
\end{abstract}


"The only thing we owe history is to rewrite it."

- Oscar Wilde

That the Great Depression in Germany led to the radicalization of the electorate is not controversial. With the unprecedented increase in unemployment, the support for the extreme right-wing NSDAP (Nationalsozialistische Deutsche Arbeiterpartei) increased dramatically, leading Germany and then the world directly into the darkest days of Western Civilization (Stögbauer 2001b). Could it have been otherwise? We explore whether the NSDAP takeover could have been averted with a fiscal policy that lowered the unemployment rate in those parts of Germany where their support increased most rapidly. A counterfactual simulation model based on estimates of the relationship between unemployment and the radical vote at the electoral district level provides a framework for considering how much lower unemployment would have to have been in these districts to prevent the NSDAP from becoming a formidable political force in Germany. ${ }^{2}$ Budget neutrality is strictly maintained, so that the simulations do not depend on an expanded fiscal policy. Instead, expenditures, and thereby also unemployment, are reshuffled among electoral districts in a way that increases government expenditures in regions where the propensity to vote for the NSDAP was highest and reduces them in those areas where they were lowest. Thus, the model redistributes unemployment spatially, without further burdening the already over-stretched Weimar budget.

The results indicate that such a policy could well have averted the NSDAP takeover, and the catastrophe that followed inextricably in its wake, without an increase in government expenditures. Financial considerations alone did not impose a binding constraint on decisive government action in defense of the Republic. However, this counterfactual analysis does not imply -- and this should be made clear at the very outset -- that the government was actually capable of mustering the will to bring such an economic program into effect. In that sense, the policy considered below may well not have been feasible. The participants in those momentous events were obviously unaware of the urgency and import of their decisions. Their actions were conditional on their mind-set as well as on their worldview and were inhibited by their inability to imagine the worst-case scenario. Hindsight enables us to be smarter. Nonetheless, it is useful to explore whether history could have been otherwise, if only the statesmen had the vision and were cognizant of the import of their actions, or inaction. ${ }^{3}$

\section{Introduction}




\section{Unemployment and the Weimar Electorate}

Unemployment in Germany rose to unprecedented levels during the Great Depression. Officially it reached some 6 million in the beginning of 1932, - almost a third of the labour force and stayed at that high level for more than a year before it began to recede. ${ }^{4}$ By that time, however, the Weimar Republic was in the hands of its enemies. This is the salient economic background against which the support for the NSDAP in the Reichstag elections rose from less than 3 percent in May 1928 to 37 percent by July 1932, thereby making it the largest party in the parliament. The electorate, thus, gave the leader of the party, Adolf Hitler, the right to claim the chancellorship for himself, and in January, 1933 the president actually asked him to form a government. Thus, the NSDAP seized power, and the agenda was set for the unimaginable that would follow.

The influence of the depression on the electoral success of the NSDAP is explored in Stögbauer (2001b) within the framework of a pooled time series/cross section fixed-effects model with spatial autocorrelation (Anselin, 1988, Flint 2002) in order to avoid the problems associated with ecological fallacy as in Falter (1987). Stögbauer estimated voting functions for individual parties for each electoral district $(n=830)$ from the late 1920s. In a longitudinal estimation procedure, the share of the votes at electoral district level was regressed on a constant, the unemployment rate, the real per capita income, and the share of the vote lagged by one period. ${ }^{5}$ Such voting functions were estimated for every electoral district, each with four regression coefficients for four parties (or party groupings), making a total of 13,280 district-specific regression coefficients ${ }^{6}$ (Table 1). The spatial distribution of the regression coefficients for the relationship between the unemployment rate and the share of the NSDAP vote at the district level is shown in Figure 1.

Table 1 and Figure 1 about here

\section{Counterfactual Thought Experiment}

From the earliest investigations into the determinants of Weimar elections, the question has recurred whether a different economic policy could have prevented the Nazi takeover. This issue is investigated in this paper using a simulation thought experiment using the estimated electoral district voting functions mentioned above. The effect of a regionally differentiated unemployment policy on the distribution of votes is analyzed using the electoral-district-specific regression coefficients which are estimates of the impact of the unemployment rate on voting 
patterns at the district level (Stögbauer 2001b). This regionally differentiated perspective is particularly important, because of the limited scope for fiscal policy at the beginning of the 1930s.

\section{BENCHMARKS FOR A COUNTERFACTUAL REALIGNMENT OF REGIONAL EMPLOYMENT RATES}

The aim of the counterfactual scenarios that follow is to determine how much regional restructuring of unemployment would have been needed to prevent the NSDAP's participation in the government, and thus to avoid the collapse of the Weimar Republic. ${ }^{7}$ The "republic-friendly" scenarios considered below increase the share of the votes for the parties favoring the pluralistic social order, such as the SPD (Sozialdemokratische Partei Deutschlands) and the Center Party, at the expense of the NSDAP (zero-sum changes). ${ }^{8}$ The focus is on a counterfactual policy that could have prevented either the radical parties to have a greater share of the votes than the nonradical parties, or the NSDAP from becoming the largest party in parliament based on the districtlevel voting patterns. The simulation proceeds by first identifying critical political turning points on the NSDAP's path to power. We then show that these turning points could have been influenced by rearranging unemployment spatially in such a way as to prevent the NSDAP from gaining the most votes in the elections.

\section{Benchmark 1: the Electionof July 1932}

The Weimar Republic was in an acute dilemma after the election of July 1932. The Nazis and the KPD (Kommunistische Partei Deutschlands) had a blocking majority in the Reichstag that enabled them to pass a motion of no confidence in a presidential cabinet or to rescind emergency decrees at any time. ${ }^{9}$ This blocking majority made the assumption of power by the NSDAP (in coalition with the Deutschnationale Volkspartei, DNVP) possible -- the only

combination able to form a government with broad parliamentary support at that time. ${ }^{10}$ Consequently, the Reichstag election of July 1932 is particularly important for the counterfactual scenarios explored here. Preventing the NSDAP and the KPD from gaining a majority can be regarded, therefore, as the benchmark for removing the necessary precondition for the NSDAP takeover. $^{11}$

\section{Benchmark 2: the Election of November 1932}

With a reduction of unemployment by four percent between July and November of 1932 , the economic situation eased slightly, and the NSDAP's share of the vote declined for the first time. Nonetheless, it was still the largest party in parliament by far, ${ }^{12}$ and Hitler, as the leader of 
the largest political party in parliament, asked Hindenburg to allow him to form a government. ${ }^{13}$ After much maneuvering, Hindenburg agreed. ${ }^{14}$ Hence, the NSDAP seizure of power was based on its electoral strength, and a decrease in its share of the vote would have foiled Hitler's attempt to achieve power, thereby boosting the republic's chances of survival. A reduction of the NSDAP's share to less than half the votes received by the democratic opposition can be considered a sufficiently large reduction, because then the NSDAP would have been only the second largest party in parliament then after the SPD. ${ }^{15}$

\section{STRUCTURE OF THE COUNTERFACTUAL SIMULATION MODEL}

The effects that an alternative economic policy might have had on the political collapse of the Weimar Republic have been analyzed explicitly in two studies using econometric methods (Frey and Weck 1981; van Riel and Schram 1993). On the basis of their estimates of a strong positive relationship between the deterioration in the employment rate, and the NSDAP's electoral success both studies concluded that the Nazi takeover would not have been possible if there had not been such a precarious increase in unemployment.

These earlier studies considered the effect of a change in the number of unemployed at the aggregate level. That is, they assumed implicitly that the relationship between the economic situation and voting behavior was homogeneous throughout Germany. In contrast, the present study considers differences in the relationship between unemployment and voting behavior at the level of electoral districts. We use a dynamic simulation model based on voting functions in specific electoral districts in order to consider this issue empirically (Stögbauer 2001a,b). On that basis, this investigation examines how the reshuffling of employment in different regions would have affected the election results. We compare the voter shares predicted by the model under alternate economic scenarios to the actual electoral outcomes. A deliberate attempt to influence employment is the only economic policy instrument considered. For a more detailed examination of the issues see (Stögbauer 2001a,b).

\section{Assumptions}

The different simulation scenarios reshuffle unemployment by means of a fiscal transfer system of regionally differentiated taxes and subsidies. We assume that these fiscal measures lead to the desired employment levels and to the predicted voting effects without a time lag. Dynamic second-order effects not captured in the model, such as the positive or negative regional growth effects that might follow from changes in unemployment, are not considered. ${ }^{16}$ Possible 
interactions between variables not endogenous to the model -- for example, the relationship between the unemployment rate and wages - are also left out of consideration. Finally, it is assumed that unemployment persisted only as a result of high real wages. Given the deflationary background, which caused real wages to rise despite falling nominal wages, this assumption seems quite appropriate. ${ }^{17}$ Given that the NSDAP was the only serious political threat to the Weimar government, the simulations assume that the government would deliberately influence the labor market in order to reduce the NSDAP's vote and strengthen its own position. ${ }^{18}$

\section{Estimation Method}

The relationship between unemployment and the NSDAP's share of the vote at electoraldistrict level was estimated by Stögbauer $(2001 \mathrm{a}, \mathrm{b})$. Regression coefficients $\left(b_{i(U N)}^{N S D P}\right)$ were estimated for 830 electoral districts for the five federal elections during the period May 1928 to March 1933. We use these estimates in order to influence the unemployment rate at the electoral district level. Unemployment is lowered stepwise in those electoral districts for which the districtspecific regression coefficients were positive, i.e., unemployment in those districts increased the NSDAP share of the vote $\left(b_{i(U N)}^{N S D A P}>0\right) i=1, \ldots, n$. This reduction in unemployment $\left(L_{0}\right.$ to $L_{1}$ or $\Delta \mathrm{A} L(-)$ in the upper panel of Figure 2), is achieved by paying a government subsidy, $s$ per new employee, to firms in these districts. ${ }^{19}$ In this way, labor demand in these districts is increased from $L_{0}^{d}$ to $L_{1}^{d}$. The total subsidy cost needed to increase employment from $L_{0}$ to $L_{1}$, is given by the area $\mathrm{ABCD}$.

Figure 2 about here

In order to avoid the subsidies from imposing an additional burden on the government budget, they are offset in this model by interventions in electoral districts with $b_{i(U N)}^{N S D P}<0$. These were districts which were faithful to the non-radical parties in spite of the increase in unemployment rate. In order to raise the revenue required to increase employment, the employment of labor in these electoral districts is taxed at a rate $t$ (lower panel of Figure 2). As a consequence, the demand for labor shifts down from $L_{0}^{d}$ to $L_{1}^{d}$ and employment falls from $L_{0}$ to $L_{1}$, or unemployment increases by $\triangle A L(+)$. The tax revenue is given by the area EFGH.

An auxiliary condition set for the simulation is that the tax rate $t$ should be determined in such a way that total tax revenue over all the electoral districts is equal to total subsidy cost and therefore that the level of the government budget remains unchanged. The total tax revenue 
collected is the transfer volume. The transfer volume is also equal to the total subsidies provided to the areas where the propensity for the unemployed to vote for the NSDAP was high. Hence, from a fiscal point of view, this model's counterfactual intervention has a zero-sum effect. This fiscal condition is necessary because at the start of the 1930s the government was facing an acute financial crisis and had little scope for financing employment programs through borrowing (Borchardt 1979; Ritschl 1998, Ritschl 2002). Therefore, the transfer volume does not provide an additional burden on the government's budget.

In addition to the subsidy and tax rates, the wage elasticity of demand for labor (the slope of $L^{d}$ in Figure 2) is also needed to determine the size of the subsidy. However, it is not possible to estimate district-specific demand elasticities with the available data; information over time at the district level on the number of employed and on real wages would be needed for such an exercise. Since time series data are unavailable in sufficient quantity, the counterfactual model has to be based on aggregate estimates from prior studies. We assume that these elasticities are applicable to all the electoral districts. The estimates of real wage elasticities range from -0.15 (Dimsdale and Horsewood 1989) to -1.36 (Corbett 1991). ${ }^{20}$ For the following calculations a real wage elasticity of -1.0 - at the upper range (in absolute value) of plausible values - is assumed, for the sake of simplicity. ${ }^{21}$ In the end it would have made little difference to use an even larger value (in absolute terms), because the final calculated transfers are minute in any event, and their sensitivity to the elasticity is small.

\section{Intervention Dates}

Two counterfactual scenarios are considered. The unemployment rate is changed either temporarily by a single stimulus: a short-term reduction for a certain Reichstag election with a subsequent return to the initial situation, or it can be changed permanently through a shift in the level of stimulus (Figure 3). However, high levels of unemployment tended to persist for an extended period time; thus, in order to show how a change in the structure of employment influenced the development in the model over time, the temporary unemployment reduction is used only for conceptual reference purposes in order to demonstrate the persistence of shocks to the economic-political system. By including the temporal autoregressive "memory" variable "share of the vote in the preceding election" in the regressions, the electoral model implies that influences on an election from the previous period (such as the past employment situation) persist over time and affect the current and future shares of the vote. The higher is the regression 
coefficient for the lagged share of the vote, the more pronounced is the degree of persistence (Bennet 1979, 41).

Figure 3 about here

With a single - once and for all - stimulus change in unemployment, the transfer volume relates to a week's income. This is the case, because we assume that the subsidy disappears after the election, and thus that there are no further regional transfer payments in this scenario. We include this scenario not because we think that it would have been realistic, but in order to illustrate the effect of the autoregressive coefficients. With the permanent variation, in contrast, the transfer amount of the monetary redistribution is expressed in weekly wages over the duration of the intervention--that is, 29 weeks as follows: from August to October (12 weeks), from November to February (16 weeks), and the first week of March, 1933.

The following counterfactual scenarios are investigated below:

\section{Scenario 1: Single Fiscal Stimulus, in July 1932}

In this model unemployment is temporarily reduced through subsidies to the electoral districts with a positive relationship between the unemployment rate and the NSDAP share of the vote $\left(b_{i(U N)}^{N S D A P}>0\right)$ only for one week prior to the election of July 1932. As an offsetting measure, the intervention implies an increase in revenue by taxing the employment of labor in the districts with $b_{i(U N)}^{N S D P}<0$, and unemployment in those districts is assumed to rise. The policy remains revenue neutral. Subsidies cease after the election, so that the unemployment rate rebounds to its previous levels. Nonetheless, subsequent elections are influenced to a small degree on account of the fact that the model includes a term on the share of the vote in the previous election. Hence, there is some persistent effects even of a short-term reduction in unemployment, and we include this scenario in order to illustrate the effect of the autoregressive coefficients, and not because we consider it a particularly convincing policy.

\section{Scenario 2a: Fiscal Stimulus Increased permanently in July 1932}

In this model unemployment is reduced in the electoral districts with $b_{i(U N)}^{N S D A P}>0$ from July 1932 for the remainder of the observation period. As in the scenario above, a tax on the employment of labor is imposed as an offsetting measure and, thus, there is an increase in unemployment in the electoral districts with $b_{i(U N)}^{N S D A P}<0$. The policy remains revenue neutral. Given 
that the persistence of the unemployment rate was high, this scenario is more plausible than the preceding one.

Scenario 2b: Fiscal Stimulus Increased permanently in July 1932 in the top four

\section{Quantiles of the districts only}

This model is a modification of scenario $2 \mathrm{a}$. In this case, unemployment is not reduced in all of the electoral districts in which $b_{i(U N)}^{N S D A P}>0$, but only in those in which the propensity to vote radical right wing is in the top four quantiles of all values - that is, in the 80 percent of the districts where the positive relationship between unemployment and the NSDAP share of the vote was the most pronounced. To compensate, a tax on the employment of labor in all districts with $b_{i(U N)}^{N S D P}<0$ is still assumed as a countervailing measure. Hence, the fiscal policy remains revenue neutral.

\section{RESULTS OF THE COUNTERFACTUAL SIMULATIONS}

This section presents the estimated electoral effects of the counterfactual scenarios described above which depend on the amount by which unemployment is reduced in the target districts and, in turn, on the amount of subsidies (transfer volume) to these districts.

\section{Electoral Effects}

Numerous simulation runs indicated that a counterfactual spatial restructuring of unemployment had a clear effect mainly after the election of September 1930. Until then the NSDAP was a miniscule party gaining but three percent of the votes. In September 1930 however, it first gained national prominence, becoming the second largest party. Our simulations therefore assume that the electoral gains of 1930 could not have been predicted, and that intervention influencing parliamentary elections would have made sense only beginning with the next election, that is to say, in July 1932. Therefore, the following scenarios focus on government interventions during the period from July 1932 to March 1933, although the econometric model estimating the effect of unemployment on the NSDAP share of the vote extends from 1928 to 1933 (Stögbauer, 2001b). In order to show the results on the democratic vote, the relevant voter shares are aggregated into the following two blocks:

- Non radical parties [SPD, Center/BVP, DVP, DDP, DNVP, splinter parties] minus NSDAP minus KPD (relevant for benchmark 1);

- SPD minus NSDAP (relevant for benchmark 2). 
Actual election results are shown in Table 2. These pertain to the radical advantage vis-àvis the other parties, and to the Nazi advantage vis-à-vis the SPD. The results of the simulations should be compared to these values.

Table 2 about here

\section{Interpretation of the diagrams}

Figures 4-7 show the differences between voter shares of the various political party aggregates and different counterfactual intervention intensities. Although we use a linear estimation model, most of the curves are nonlinear, because variables from several voter shares of the individual parties are combined for the aggregate estimates. The differences in the voter shares shown (on the Y-axis) indicate the amount by which the democratic parties' share together exceeded that of the radical vote (benchmark 1), and the amount by which the SPD vote exceeded the vote for the Nazi party (benchmark 2). The amount by which unemployment in the electoral districts $b_{i(U N)}^{N S D A P}>0$ is reduced is shown on the $\mathrm{X}$-axis. This indicates the intensity of the counterfactual intervention in the labor market, and depends on the transfer volume - the subsidies to the target districts. The actual policy instrument -- the government subsidy to provide employment for the unemployed, - is not indicated directly in the diagram. Nevertheless, the presentation permits an intuitive understanding of the intensity of the fiscal measures. Because in

this counterfactual model, unemployment is reduced in electoral districts with $b_{i(U N)}^{N S D A P}>0$ and increased in those districts with $b_{i(U N)}^{N S D A P}<0$, the NSDAP share of the vote should decline as a consequence of the fiscal intervention. The amount by which the NSDAP's share of the vote declines depends on the size of the estimated district-specific regression coefficient. The results of the scenarios examined below show that the desired reduction in the NSDAP share of the vote can be accomplished by the different counterfactual scenarios without additional burden on the government's budget.

Figures 4-7 can be interpreted as follows. There are separate diagrams for the two counterfactual intervention types considered and for the two types of voting outcomes sought. There are three curves in each diagram, with the lines representing the differences in voting shares for different Reichstag elections pertaining to labor market interventions of different intensities (different amounts of transfers). The values where the curves intersect the $\mathrm{Y}$-axis are the predicted values of the differences in voter shares without any government intervention. 
(These values might differ slightly from the actual values reported in Table 2, insofar as the model does not predict the actual - historical - values perfectly.) Hence, where a curve exceeds zero on the Y-axis, the corresponding counterfactual scenario for the respective Reichstag election achieves the goal of stabilizing the Weimar Republic: the democratic share becomes greater than the radical share, or the SPD share becomes greater than the NSDAP share.

\section{Interpretation of the tables}

The corresponding values for the diagrams are reported in Tables 3 and 4. The values in the top panel of each scenario refer to the difference between the voter shares of the democratic parties and those of the radical parties (Table 3) or the difference between the voter shares of the SPD and the NSDAP (Table 4). The tables give these differences for the different intervention intensities. The column "Elections" gives the election dates to which the results of the counterfactual voting scenarios pertain. In addition, the tables also give the absolute number of unemployed (in millions) before and after the counterfactual intervention under the heading "Effect of the Intervention". In turn, this category is subdivided into two parts: electoral districts in which unemployment is reduced in order to achieve political stabilization (the districts with $b_{i(U N)}^{N S D A P}>0$ are denoted by $\left.\mathbf{U N} \downarrow\right)$, and districts in which unemployment is increased in order to obtain fiscal neutrality (those with $b_{i(U N)}^{N S D A P}<0$ are denoted as $\mathbf{U N} \uparrow$ ). The third row of the bottom panels "Transfers" give the subsidy (in millions of RM) that would have been needed to lower unemployment in the target districts. As noted above, this amount is financed by equivalent taxation in the non-target districts so that in total the policy measure is fiscally neutral. The model is simulated for various levels of intervention intensities. In Table 3 top panel, the intensities vary from $1 \%$ to $10 \%$. That is to say, unemployment in the target districts (the districts with $b_{i(U N)}^{N S A P}>0$ ) would have been reduced by these percentages. For example, consider, say, the $7^{\text {th }}$ column $(7 \%)$ : a single (once-and-for-all) transfer of circa 0.18 millions RM (180,000 RM) the week before the election in July 1932 would have sufficed to decrease unemployment from 3.3 millions to 3.25 millions (i.e., by 7\%) in the districts with a high propensity to vote radical, while increasing unemployment from 0.72 millions to 0.77 millions in the other districts. This intervention would have given the democratic parties a 7.93 percent lead over the radical parties in the July 1932 elections -- instead of an actual 3.8 percent lag (Table 2). If nothing else had been done thereafter, the two blocks would have received approximately equal shares of the votes in November 
(11/1932) -- practically no difference in this election compared to the actual outcome (0.06) --, and in March of 1933 the democratic block would still have been trailing the radical block by 9,09 percent -- instead of the actual 12 percent. However, in order to obtain a larger voter share for the democratic parties than that of the radical parties for all three elections between July 1932 and March 1933, the unemployment rate in the target districts would have to have been decreased by $6 \%$ permanently over the entire period of observation (scenario 2a, bottom panel, Table 3), with a transfer volume of some 3.73 million RM. Even with such tiny amounts of transfers the democratic parties would have had a larger voter share than that of the radical parties.

Table 3 about here

\section{Benchmark 1: Difference between the voting shares of the non-radical parties and the}

\section{radical parties}

\section{Scenario 1}

Figure 4 show that a once-and-for-all reduction of unemployment in the electoral districts with $b_{i(U N)}^{N S A P}>0$ in July 1932 would have had a large effect on that election (represented by the solid line). In the actual distribution of the votes, the radical parties together had a lead of 3.8 percent over the democratic parties (Table 2). However, this outcome could have been reversed

with a relatively small rearrangement of unemployment of only 2.3 percent (Figure 4$).{ }^{24}$ The more intensive the regional fiscal intervention would have been in July 1932, the stronger would have been the movement of voters away from the radical camp. This shows that the aim of the counterfactual scenario -- to avoid one of the necessary conditions for the Nazi takeover, namely, the blocking majority of the radical parties following the election of July 1932 -- could have been achieved with a small labor market intervention. For this level of labor market intervention (2.3 percent) the subsidy for increasing the income for the duration of one week in the target districts would have amounted to only about 10,000 RM (Table 3).

Figure 4 about here

This result is obtained because the democratic parties would have gained votes at the expense of the NSDAP. With a reduction in the unemployment rate of between 1 percent and 10 percent, the Nazi share of the vote would have fallen from about 35 percent to 27 percent, while the KPD share would have essentially remained constant at 14 percent. The reason for this pattern is that support between the NSDAP and the KPD was socio-economically and regionally determined. There was a very weak negative relationship between an increasing unemployment 
rate and support for the KPD in the electoral districts where the positive relationship between increasing unemployment and the NSDAP share of the vote was pronounced. The increasing lead of the non-radical parties over the radical parties is based on the increase in the vote for both the government (rising from 7.6 percent to 12.7 percent) and the other democratic parties (rising from 43.6 percent to 46.5 percent). In the electoral districts selected for the counterfactual simulation there is a trade-off concerning the effect of changes in the unemployment rate on the voting shares between the NSDAP and the non radical Weimar parties.

The rearrangement of unemployment for the July 1932 election also has an effect on the next elections through the lagged voting-share variable, even though unemployment is assumed to return to its starting level subsequently. The effect of the temporary change in the unemployment rate a few months earlier (in July 1932) on the November 1932 election is weak or non-existent (Figure 4). For the election in March 1933, in contrast, the counterfactual (once-and-for-all) intervention in July 1932 results in a stronger showing of the democratic parties compared to the actual election results, because of the lagged effect. Yet, this effect is not sufficient to push the voting share of the radical parties below that of the democratic ones.

\section{Scenario $2 a$}

However, the redistribution of the votes in favor of the democratic parties is more pronounced with scenario $2 \mathrm{a}$ (Figure 5). This is the case because, in addition to the continuing effect through the lagged voting-share variable, the reshuffling of unemployment for 29 weeks results in the increased voter's share of the democratic parties at the expense of the radical ones. Yet, the intensity of fiscal intervention is higher in this scenario because the regional (mutually compensating) subsidy/tax flows last for 29 weeks and not only for one week. Overall, the electoral effect of the counterfactual model is sufficiently pronounced that, even for the election in March 1933, a redistribution of a mere 5.5 percent of the unemployed would have sufficed to prevent the radicals from gaining a blocking majority of seats in parliament (Figure 5).

Figure 5 about here

\section{Benchmark 2: Difference between the voter shares of the SPD and the NSDAP}

For the election in November 1932, the goal was to push the NSDAP's share of the vote below that of the SPD as the second benchmark for a successful counterfactual rearrangement of unemployment. This outcome would have removed another condition for the Nazi takeover, namely, Hitler would have been deprived of being the leader of the strongest coalition in January 
1933. For this benchmark we do not consider scenario 1, because a subsidy in July would have had only a weak effect in November of 1932.

\section{Scenario $2 a$}

In order for the SPD to achieve a lead over the NSDAP in November 1932, an intervention intensity would have been necessary to reduce the unemployment by about 35 percent in the electoral districts with $b_{i(U N)}^{N S D A P}>0$ (Figure 6 and Table 4). Thus, the second goal of the counterfactual simulation -- to prevent a Nazi lead over the SPD in the November 1932 election -- would have required a larger intervention than that needed to prevent the blocking majority of the radicals in parliament after the July 1932 election. This is the case because the actual difference between the voter shares of the SPD and that of the NSDAP was -12.7 percent whereas the difference between the voter shares of the non-radical and that of the radical parties in July 1932 was -3.8 percent (Table 2). In other words, benchmark 2 is always a more stringent condition to meet.

Figure 6 and Table 4 about here

\section{Scenario $2 b$}

The counterfactual intervention in scenario $2 \mathrm{~b}$ takes place in only those electoral districts in which the coefficient of the voting propensity for the NSDAP with respect to unemployment was in the top $80 \%$-- that is, unemployment is only reduced in those districts for which $b_{i(U N)}^{N S D P}>1.83$. The compensating increase in unemployment is still allotted to all electoral districts with $b_{i(U N)}^{N S D P}<0$. This scenario takes advantage of the fact that a given reduction in unemployment in these districts has a much stronger electoral effect than in the other districts; thus, a shift in votes of a certain magnitude is possible with lower intervention intensity. With scenario $2 \mathrm{~b}$ for the decisive Reichstag election of November, 1932, an intervention intensity of about $40 \%$ would produce the desired result, a larger share of the vote for the SPD than for the NSDAP (Figure 7). Although this level of intensity is somewhat larger than in scenario $2 \mathrm{a}$, the next section shows that scenario $2 \mathrm{~b}$ requires a smaller transfer volume than scenario $2 \mathrm{a}$ (Table 4 ).

Figure 7 about here

\section{Transfer Volume}

In addition to the electoral effects of the different counterfactual interventions, Tables 3 and 4 give the amounts of the transfers and the resulting adjustments in the labor market. The transfer volume refers to the monetary redistribution associated with the intervention intended to 
influence the regional employment structure. These amounts are needed to provide labor demand subsidies in order to reduce unemployment in the targeted electoral districts. Equivalent taxes are imposed in other districts in order to maintain budget neutrality. The "transfer volume", thus does not impose a net burden on the government budget.

The effectiveness of the intervention can be increased by limiting the measures to those districts where the relationship between unemployment and the NSDAP share of the vote is particularly pronounced (Table 4 and Figure 6). ${ }^{25}$ For example, in scenario $2 \mathrm{a}$ the (budget-neutral) transfer needed to reach the counterfactual benchmark in November 1932 is about 127 million Reichsmarks (RM) -- an intervention that would have reduced unemployment by about 35 percent in the targeted districts (Table 4, top panel). This would have given the SPD a greater voter share than that of the NSDAP. In scenario $2 b$, in contrast, while unemployment would have to have been decreased by 45 percent, only about 110 million RM would have to have been transfered to achieve this goal -- that is, about one-fifth less (Table 4, bottom panel).

\section{PLAUSIBILITY OF THE SIMULATION SCENARIOS}

The above counterfactual simulation exercises imply that two key conditions for the Nazi takeover after the elections of 1932 could have been avoided if the regional employment structure had been altered. In other words, it would have been possible to prevent the political collapse of the Weimar Republic without a particularly large government intervention, and by maintaining budget neutrality. The question arises how plausible the simulated scenarios are and whether they could actually have been realized within the Weimar governments' scope of action with the policy instruments available to them at the time. ${ }^{26}$ This question can be illuminated by considering the form and magnitude of the measures actually introduced to combat unemployment during the twilight of the Republic (July 1932 to March 1933).

The most important employment policy initiative within this period was that implemented within the framework of the emergency decree of September 4, 1932, by Chancellor Papen. The following steps were planned: a) government job creation measures, to be financed with up to 135 million RM from the current budget (Henning 1993, 137f.); b) tax credits of 700 million RM (this amount was increased by 500 million RM in January 1933 under Chancellor Schleicher), to be paid to firms giving jobs to the unemployed; c) borrowing of 302 million RM to finance public works. In terms of their fiscal effect, all these proposals differ from those used in the model in that they impose a net burden on the government budget. This applies particularly to the second 
measure. Although it did not burden the government budget immediately, it did so when the credits were used to pay taxes and customs duties in subsequent periods. In terms of its effects on the labor market, however, the second measure used essentially the same mechanism as that described above. The reduction of the tax burden worked like a subsidy for employing the unemployed and, from the point of view of the firm, resulted in a reduction in the costs of employing that person. Thus, the counterfactual labor market intervention proposed here is basically plausible as the starting point for an employment policy intervention in light of the actual programs that were introduced.

As a constant total budget is an auxiliary condition for the above counterfactual scenarios, there is no net burden on the government budget. In the scenario associated with the highest level of intervention (benchmark 2, scenario 2a, the sum needed for a budget-neutral redistribution was 127 million RM; this was smaller than the actual sums in the then-current budget set aside for fighting unemployment (135 million RM). The regional welfare compensation program, which was implemented in the Weimar Republic as part of the so-called Osthilfe, constitutes another useful comparison, especially with regard to spatial unemployment redistribution. ${ }^{27}$ The immediate goal of the Osthilfe program was to reduce the heavy debt burden of the large agricultural units in eastern Germany. This program was financed from the revenue realized from a levy on industry (Industrieaufbringungsumlage). ${ }^{28}$ In 1931, the revenue from this levy amounted to 50 million RM, and it rose to 120 million in 1932 (Raupach 1967, 25). This sum was about equal to the amount that would have been needed for the budget-neutral transfer required for scenarios $2 \mathrm{a}$ and $2 \mathrm{~b}$. The aim of this transfer was to prevent the NSDAP from becoming the strongest group in the November 1932 election. The order of magnitude calculated in the simulation -- which, unlike the actual policy measures, effectively put no additional burden on the budget -- was therefore within the purview of the policy makers at the time.

\section{Conclusion}

This model demonstrates that the collapse of Weimar democracy was not necessarily inevitable, given the economic situation and the constraints on the government's budget. With a different fiscal policy, alternative voting patterns might well have emerged with a sufficiently smaller NSDAP share of the total vote to prevent it from becoming the largest political party in the elections of 1932. We assume that the voters or firms would not have behaved strategically and would not have increased the unemployment rate in anticipation of the subsidies. ${ }^{29}$ 
Counterfactual simulation models are used to identify critical turning points for the NSDAP's bid for power in the elections in 1932 and 1933. These models enable us to examine whether the electoral outcome could have been turned in favor of the democratic parties using fiscal policy instruments that reallocated unemployment spatially across Germany. The above simulations indicate that, even with tiny budget-neutral regional transfers necessary parliamentary milestones on the path to the Nazi seizure of power could have been prevented (Figure 8). The radical lead over the non-radical parties was less than four percent, so that a mere two-percent change in the election of July 1932 could have sufficed to reverse the NSDAP's rise to power. Hence, the Third Reich does not appear to have been the only conceivable alternative available to the fledgling democracy, and all that followed from its demise could well have been otherwise with a more activist fiscal policy. Weimar needed desperately to wage war on unemployment, and it would not have taken much money to do so effectively. Of course, a number of alternative transfer schemes would have been possible, such as increasing the general tax rate at the national level and reallocating the proceeds to those districts that were most likely to vote for the NSDAP. The transfers needed to purchase the necessary votes in these districts are so tiny that even a net increase in the budget expenditures would have been a possibility. In short, many other counterfactual models could be considered. The above models should be considered as just one set of specifications that indicate that the NSDAP's electoral successes could have been thwarted.

Figure 8 about here

An analogy to the overall strategy can be drawn with Franklin Roosevelt's revolutionary "New Deal" programs to save capitalism in the US. Roosevelt did design political spending in order to gain political advantage in upcoming elections. His successful reelections were based, in part, on spending for political purposes. He did, in fact, distribute New Deal funds across 3,000 U.S. counties in such a way as to gain political advantage in upcoming elections (Fishback, Kantor and Wallis, 2003). Thus, there were political leaders who did recognize the seriousness of the situation, and acted accordingly. Other political were able to influence elections. Hence, the counterfactual programs discussed above are not as far-fetched as they appear at first glance. Weimar failed not only because of the Great Depression, and not only because of the gravity of the economic and budgetary situation, but also because it lacked political leaders with sufficient experience to recognize the gravity of the situation, and a broad-enough vision to imagine the worst-case consequences of their inaction. 
Table 1. Summary of the coefficients for (830) electoral-district-specific voting functions, averaged over the whole of Germany

\begin{tabular}{|c|c|c|c|c|}
\hline Variable & NSDAP & KPD & Government & $\begin{array}{l}\text { Democratic } \\
\text { Opposition } \\
\end{array}$ \\
\hline Constant & .030 & -.016 & .058 & -.018 \\
\hline $\begin{array}{l}\text { Unemployment } \\
\text { rate }\end{array}$ & $\begin{array}{l}1.65 \\
{[.79]}\end{array}$ & $\begin{array}{l}0.13 \\
{[.081]}\end{array}$ & $\begin{array}{l}-2.28 \\
{[-1.28]}\end{array}$ & $\begin{array}{l}1.59 \\
{[0.22]}\end{array}$ \\
\hline $\begin{array}{l}\text { Weekly per } \\
\text { capita real } \\
\text { income }\end{array}$ & $\begin{array}{l}-.003 \\
{[-.61]}\end{array}$ & $\begin{array}{l}.003 \\
{[1.28]}\end{array}$ & $\begin{array}{l}.000 \\
{[.43]}\end{array}$ & $\begin{array}{l}.018 \\
{[1.16]}\end{array}$ \\
\hline $\begin{array}{c}\text { Lagged share of } \\
\text { votes }\end{array}$ & $\begin{array}{l}.033 \\
{[.127]}\end{array}$ & $\begin{array}{l}.015 \\
{[.047]}\end{array}$ & $\begin{array}{l}.163 \\
{[.239]}\end{array}$ & $\begin{array}{l}-.057 \\
{[-.20]}\end{array}$ \\
\hline
\end{tabular}

Note: The estimation procedure assumed that the number of votes cast at the district level remained constant so that the changes in the voter preferences add up to zero. The voter shares add up to $100 \%$ through cross-regression restrictions at the district level.

Numbers in brackets are point elasticities at the average of the respective variables; as variables are measured in different units (incomes in Reichsmarks, unemployment as a percentage of the work force, votes as a percentage of the electorate), the elasticities can be used to compare the relative effect of the different variables. Example: an increase in unemployment by $1 \%$ causes the NSDAP share to rise by $0.08 \%$ and that of the government to fall by $1.3 \%$.

Source: Stögbauer $2001 b$.

Table 2: Differences between the actual shares of the votes

\begin{tabular}{rcc}
\multicolumn{1}{c}{ Elections } & $\begin{array}{c}\text { Non Radicals } \\
\text { minus Radicals }\end{array}$ & $\begin{array}{c}\text { SPD minus } \\
\text { NSDAP }\end{array}$ \\
\hline \hline $7 / 1932$ & -3.8 & -15.8 \\
\hline $11 / 1932$ & 0.0 & -12.7 \\
\hline $3 / 1933$ & -12.4 & -25.6 \\
\hline
\end{tabular}


Table 3: Effect of different counterfactual interventions: Difference in voter shares between democratic parties (SPD, Center Party/BVP, DVP, splinter parties) and the radical parties (NSDAP, KPD) (Percent)

\section{SCENARIO 1: Once-and-for-all Stimulus 7/1932}

Extent of Intervention: The percent by which unemployment is reduced in the electoral districts where $b_{i(U N)}^{N S A P}>0$

\begin{tabular}{|c|c|c|c|c|c|c|c|c|c|c|c|c|c|c|c|c|c|c|c|c|}
\hline Elections & \multicolumn{2}{|c|}{$1 \%$} & \multicolumn{2}{|c|}{$2 \%$} & \multicolumn{2}{|c|}{$3 \%$} & \multicolumn{2}{|c|}{$4 \%$} & \multicolumn{2}{|c|}{$5 \%$} & \multicolumn{2}{|c|}{$6 \%$} & \multicolumn{2}{|c|}{$7 \%$} & \multicolumn{2}{|c|}{$8 \%$} & \multicolumn{2}{|c|}{$9 \%$} & \multicolumn{2}{|c|}{$10 \%$} \\
\hline $7 / 1932$ & \multicolumn{2}{|c|}{$-2,35$} & \multicolumn{2}{|c|}{$-0,54$} & \multicolumn{2}{|c|}{1,35} & \multicolumn{2}{|c|}{2,77} & \multicolumn{2}{|c|}{4,63} & \multicolumn{2}{|c|}{6,42} & \multicolumn{2}{|c|}{7,93} & \multicolumn{2}{|c|}{9,89} & \multicolumn{2}{|c|}{11,74} & \multicolumn{2}{|c|}{13,59} \\
\hline $11 / 1932$ & \multicolumn{2}{|c|}{0,35} & \multicolumn{2}{|c|}{0,45} & \multicolumn{2}{|c|}{0,94} & \multicolumn{2}{|c|}{0,50} & \multicolumn{2}{|c|}{0,03} & \multicolumn{2}{|c|}{$-0,10$} & \multicolumn{2}{|c|}{0,06} & \multicolumn{2}{|c|}{$-0,41$} & \multicolumn{2}{|c|}{$-0,20$} & \multicolumn{2}{|c|}{$-0,99$} \\
\hline $3 / 1933$ & \multicolumn{2}{|c|}{$-12,46$} & \multicolumn{2}{|c|}{$-12,25$} & \multicolumn{2}{|c|}{$-11,54$} & \multicolumn{2}{|c|}{$-11,32$} & -10 & ,88 & -10 &, 12 & -9 , & 09 & -8 &, 31 & -7 &, 11 & -7, & 02 \\
\hline & & & & & & & fect $c$ & of the & Intel & rventi & ion & & & & & & & & & \\
\hline Million & $\mathbf{U N} \downarrow$ & $\mathbf{U N} \uparrow$ & $\mathbf{U N} \downarrow$ & $\mathbf{U N} \uparrow$ & $\mathbf{U N} \downarrow$ & $\mathbf{U N} \uparrow$ & UN $\downarrow$ & $\mathbf{U N} \uparrow$ & $\mathbf{U N} \downarrow$ & $\mathbf{U N} \uparrow$ & $\mathbf{U N} \downarrow$ & $\mathbf{U N} \uparrow$ & UN $\downarrow$ & $\mathbf{U N} \uparrow$ & $\mathbf{U N} \downarrow$ & $\mathbf{U N} \uparrow$ & $\mathbf{U N} \downarrow$ & $\mathbf{U N} \uparrow$ & $\mathbf{U N} \downarrow$ & $\mathbf{U N} \uparrow$ \\
\hline $\begin{array}{c}\text { Unemployment at } \\
\text { the start }\end{array}$ & 3,30 & 0,72 & 3,30 & 0,72 & 3,30 & 0,72 & 3,30 & 0,72 & 3,30 & 0,72 & 3,30 & 0,72 & 3,30 & 0,72 & 3,30 & 0,72 & 3,30 & 0,72 & 3,30 & 0,72 \\
\hline $\begin{array}{l}\text { Unemployment at } \\
\text { the end }\end{array}$ & 3,29 & 0,73 & 3,28 & 0,74 & 3,28 & 0,74 & 3,27 & 0,75 & 3,26 & 0,76 & 3,26 & 0,77 & 3,25 & 0,77 & 3,24 & 0,78 & 3,23 & 0,79 & 3,22 & 0,80 \\
\hline Transfers (RM) & & 0,00 & & 0,0 & & 0,03 & & 0,06 & & 0,09 & & 0,13 & & 0,18 & & 0,23 & & 0,30 & & 0,37 \\
\hline
\end{tabular}

SCENARIO 2a: Continuous intervention after 7/1932

Extent of Intervention: The percent by which unemployment is reduced in the electoral districts where $b_{i(U N)}^{N D A P}>0$

\begin{tabular}{|c|c|c|c|c|c|c|c|c|c|c|c|c|c|c|c|c|c|c|c|c|}
\hline Elections & \multicolumn{2}{|c|}{$1 \%$} & \multicolumn{2}{|c|}{$2 \%$} & \multicolumn{2}{|c|}{$3 \%$} & \multicolumn{2}{|c|}{$4 \%$} & \multicolumn{2}{|c|}{$5 \%$} & \multicolumn{2}{|c|}{$6 \%$} & \multicolumn{2}{|c|}{$7 \%$} & \multicolumn{2}{|c|}{$8 \%$} & \multicolumn{2}{|c|}{$9 \%$} & \multicolumn{2}{|c|}{$10 \%$} \\
\hline $7 / 1932$ & \multicolumn{2}{|c|}{$-2,35$} & \multicolumn{2}{|c|}{$-0,54$} & \multicolumn{2}{|c|}{1,35} & \multicolumn{2}{|c|}{2,77} & \multicolumn{2}{|c|}{4,63} & \multicolumn{2}{|c|}{6,42} & \multicolumn{2}{|c|}{$\overline{7,93}$} & \multicolumn{2}{|c|}{$9,9,89$} & \multicolumn{2}{|c|}{1011,74} & \multicolumn{2}{|c|}{13,59} \\
\hline $11 / 1932$ & \multicolumn{2}{|c|}{1,19} & \multicolumn{2}{|c|}{2,55} & \multicolumn{2}{|c|}{3,08} & \multicolumn{2}{|c|}{3,59} & \multicolumn{2}{|c|}{4,06} & \multicolumn{2}{|c|}{4,49} & \multicolumn{2}{|c|}{5,31} & \multicolumn{2}{|c|}{5,31} & \multicolumn{2}{|c|}{5,80} & \multicolumn{2}{|c|}{5,64} \\
\hline $3 / 1933$ & \multicolumn{2}{|c|}{$-10,98$} & \multicolumn{2}{|c|}{$-9,08$} & \multicolumn{2}{|c|}{$-6,69$} & \multicolumn{2}{|c|}{$-4,98$} & -1 , & 21 & 0, & 70 & 2, & 10 & 2, & 10 & 4,2 & & 4,9 & 93 \\
\hline & & & & & & Ef & fect 0 & f the & Inter & event & ion & & & & & & & & & \\
\hline Million & $\mathbf{U N} \downarrow$ & $\mathbf{U N} \uparrow$ & $\mathbf{U N} \downarrow$ & $\mathbf{U N} \uparrow$ & $\mathbf{U N} \downarrow$ & $\mathbf{U N} \uparrow$ & $\mathbf{U N} \downarrow$ & $\mathbf{U N} \uparrow$ & $\mathbf{U N} \downarrow$ & $\mathbf{U N} \uparrow$ & $\mathbf{U N} \downarrow$ & $\mathbf{U N} \uparrow$ & $\mathbf{U N} \downarrow$ & $\mathbf{U N} \uparrow$ & $\mathbf{U N} \downarrow$ & $\mathbf{U N} \uparrow$ & $\mathbf{U N} \downarrow$ & $\mathbf{U N} \uparrow$ & $\mathbf{U N} \downarrow$ & $\mathbf{U N} \uparrow$ \\
\hline $\begin{array}{c}\text { Unemployment at } \\
\text { the start }\end{array}$ & 3,33 & 0,76 & $\mid 3,33$ & 0,76 & 3,33 & 0,76 & 3,33 & 0,76 & 3,33 & 0,76 & 3,33 & 0,76 & 3,33 & 0,76 & 3,33 & 0,76 & 3,33 & $\mid 0,76$ & 3,33 & 0,76 \\
\hline $\begin{array}{c}\text { Unemployment at } \\
\text { the End }\end{array}$ & 3,30 & 0,76 & 3,26 & 0,76 & 3,23 & 0,76 & 3,20 & 0,76 & 3,16 & 0,76 & 3,13 & 0,76 & 3,10 & 0,76 & 3,06 & 0,77 & 3,04 & 0,77 & 3,00 & 0,77 \\
\hline Transfers (RM) & & 0,104 & & 0,41 & & 0,93 & & 1,66 & & 2,59 & & 3,73 & & 5,08 & & 6,64 & & 8,33 & & 0,382 \\
\hline
\end{tabular}

Note: Top rows with \% show the amount by which unemployment in the electoral districts $b_{i(U N)}^{N S D P}>0$ is reduced. This indicates the intensity of the counterfactual intervention in the labor market. The rows with $\mathbf{U N} \downarrow$ and $\mathbf{U N} \uparrow$ indicate districts $b_{i(U N)}^{N S D A P}>0$ and $b_{i(U N)}^{N S D A}<0$ respectively; for step scenarios unemployment numbers are given as the average over three points in time, transfer volumes are given as the sum over three points in time; Tables 4 and 5 show different levels of labor market intervention: 1 to $10 \%$ and 10 to $55 \%$.

Example above scenario 2a: with a reduction of unemployment in districts with $b_{i(U N)}^{N S D P}>0$ by $4 \%$ in $7 / 1932$ and the compensating increase in unemployment in districts with $b_{i(U N)}^{N S D A P}<0$, the voter shares of the non-radical parties would have been greater than that of the radical parties by $2.77 \%$. In the districts in which unemployment is reduced the number of unemployed before the intervention was 3.33 million, and after the intervention the number would have been $4 \%$ less, 
i.e., 3.2 million. In turn, In the districts in which unemployment is increased the number of unemployed before the intervention was .76 million, and after the intervention the number would have remained at 0.76 (since the change was in the third decimal place). The number of unemployed before the counterfactual intervention is the same across the different levels of percentage changes, insofar as those are the historical values. Subsidies for increase in employment is 1.66 million Reichsmak, the same as the increases in the tax revenues. 
Table 4. Effect of different counterfactual interventions: SPD minus NSDAP voter shares

\section{SCENARIO 2a: Continuous intervention after 7/1932}

Extent of Intervention: The percent by which unemployment is reduced in the electoral districts where $b_{i(U N)}^{N S D P}>\mathbf{0}$

Elections

$7 / 1932$

$10 \%$

$15 \%$

\begin{tabular}{|l|l|}
$20 \%$ & $25 \%$ \\
\hline
\end{tabular}

$30 \%$

\begin{tabular}{|c|c|}
\hline $35 \%$ \\
\hline 9,59 \\
\hline 0,02 \\
\hline
\end{tabular}

\section{Effect of the Intervention}

Millions $\mathbf{U N} \downarrow \mid \mathbf{U N 1}$

\begin{tabular}{|c|c|c|c|c|c|c|c|c|c|c|c|c|c|c|c|c|c|c|c|c|}
\hline $\begin{array}{r}\text { Unem }_{1} \\
\text { th }\end{array}$ & 3,33 & 0,76 & 3,33 & 0,76 & 3,33 & 0,76 & 3,33 & 0,76 & 3,33 & 0,76 & 3,33 & 0,76 & 3,33 & 0,76 & 3,33 & 0,76 & 3,33 & 0,76 & 3,33 & 0,76 \\
\hline $\begin{array}{r}\text { Unem }_{1} \\
\mathrm{tl}\end{array}$ & 00 & 0,77 & 2,83 & 0,78 & 2,66 & 0,80 & 2,50 & 0,83 & 2,33 & 0,86 & 2,16 & 0,90 & 2,00 & 0,95 & 83 & 1,00 & 1,72 & 1,05 & & \\
\hline$T$ & & & & 23,36 & & 41,53 & & 54,89 & & 93,44 & & 7,18 & &, 11 & & 23 & & 3,71 & & \\
\hline
\end{tabular}

\section{SCENARIO 2b: Continuous intervention after 7/1932 in districts in which $b_{i(U N)}^{N S D A P}>1.83$}

Effect intervention: The percent by which unemployment is reduced in the electoral districts where $b_{i(U N)}^{N S D P}>\mathbf{0}$

\begin{tabular}{|c|c|c|c|c|c|c|c|c|c|c|}
\hline Elections & $10 \%$ & $15 \%$ & $20 \%$ & $25 \%$ & $30 \%$ & $35 \%$ & $40 \%$ & $45 \%$ & $50 \%$ & $55 \%$ \\
\hline $7 / 1932$ & $-5,38$ & $-0,25$ & 3,47 & 6,74 & 10,22 & 12,78 & 14,77 & 16,49 & 17,22 & 17,78 \\
\hline $11 / 1932$ & $-8,37$ & $-6,65$ & $-5,37$ & $-3,11$ & $-1,30$ & $-0,44$ & $-0,16$ & 0,16 & 0,50 & 0,34 \\
\hline $3 / 1933$ & $-16,79$ & $-12,87$ & $-9,69$ & $-7,49$ & $-3,60$ & $-0,98$ & 1,38 & 1,54 & 4,02 & 3,70 \\
\hline
\end{tabular}

\section{Effect of the Intervention}

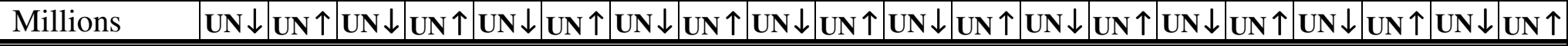
\begin{tabular}{l|l|l|l|l|l|l|l|l|l|l|l|l|l|l|l|l|l|l|l|l|}
\hline \hline Unemployment at & 2,08 & 0,76 & 2,08 & 0,76 & 2,08 & 0,76 & 2,08 & 0,76 & 2,08 & 0,76 & 2,08 & 0,76 & 2,08 & 0,76 & 2,08 & 0,76 & 2,08 & 0,76 & 2,08 & 0,76 \\
\hline
\end{tabular} the start

\begin{tabular}{lll|l|l|l|l|l|l|l|l|l|l|l|l|l|l|l|l|l|l}
\hline Unemployment at & 1,88 & 0,76 & 1,77 & 0,77 & 1,67 & 0,78 & 1,56 & 0,80 & 1,46 & 0,81 & 1,35 & 0,83 & 1,25 & 0,86 & 1,15 & 0,88 & 1,07 & 0,93 & 0,97 & 0,94 \\
\hline
\end{tabular} the end

Transfers (RM)

$\begin{array}{ll}5,46 & 12,28\end{array}$

21,83

34,10

49,08

66,60

87,25

110,52

129,23

149,70

Notes: See Table 3 
Figure 1: Spatial distribution of the electoral-district-specific regression coefficients for the relationship between unemployment rate and the NSDAP share of votes

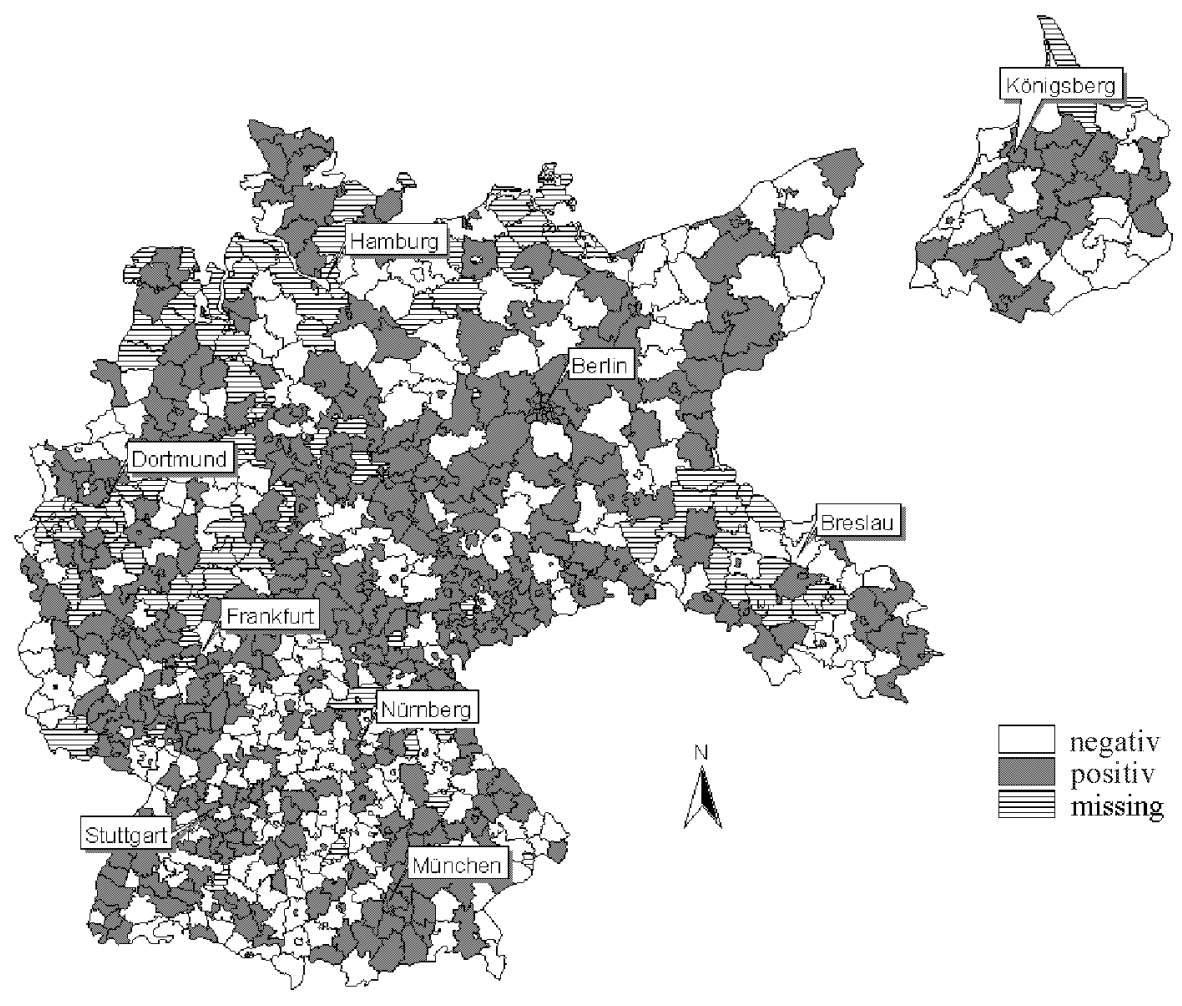


Figure 2: Mechanism for the regional re-structuring of unemployment
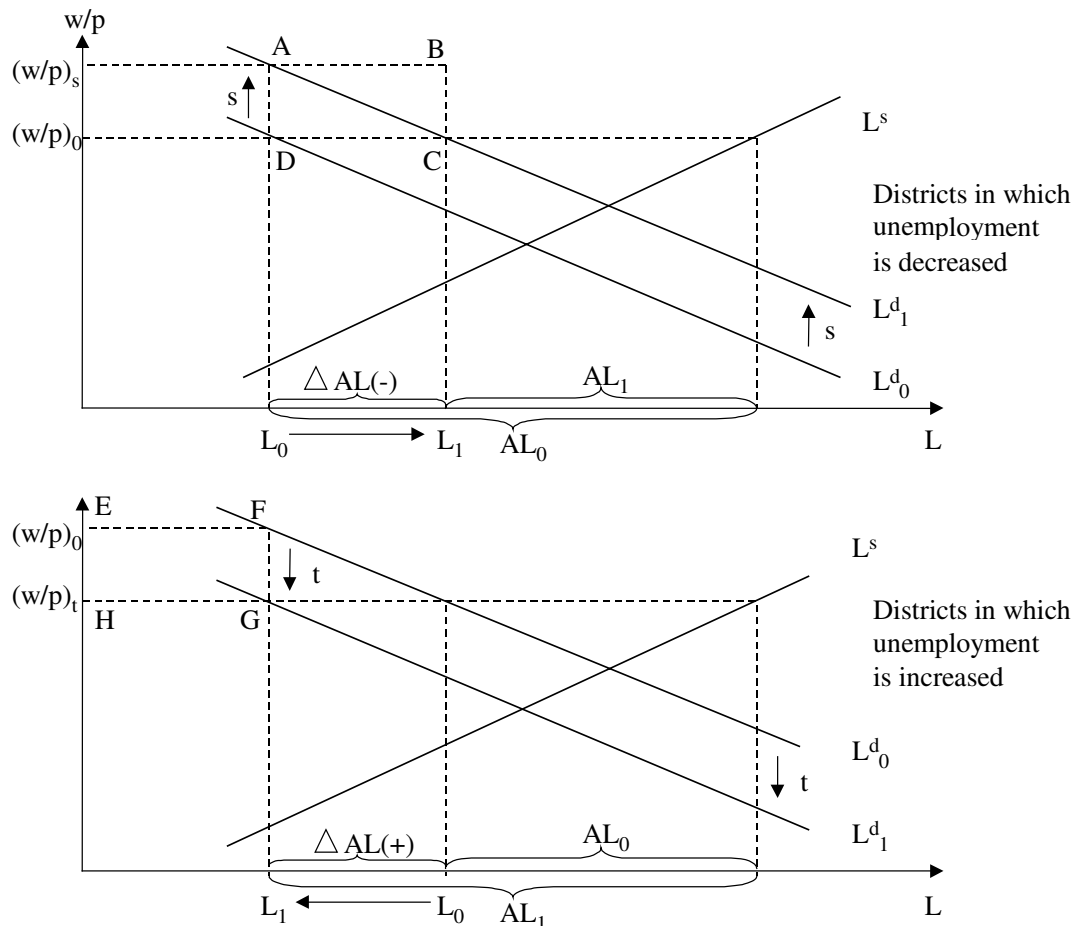

Indices 0 and 1 denote before and after counterfactual restructuring of the regional structure of unemployment.

$w / p:$ Real wage

$L^{s}$ : Labor supply

$L^{d}$ : Labor demand

$A L:$ Unemployed

$s: \quad$ Subsidy rate

$t$ : Tax rate 
Figure 3: Numbers of Unemployed in Munich electoral district and Duration of a counterfactual intervention: two scenarios
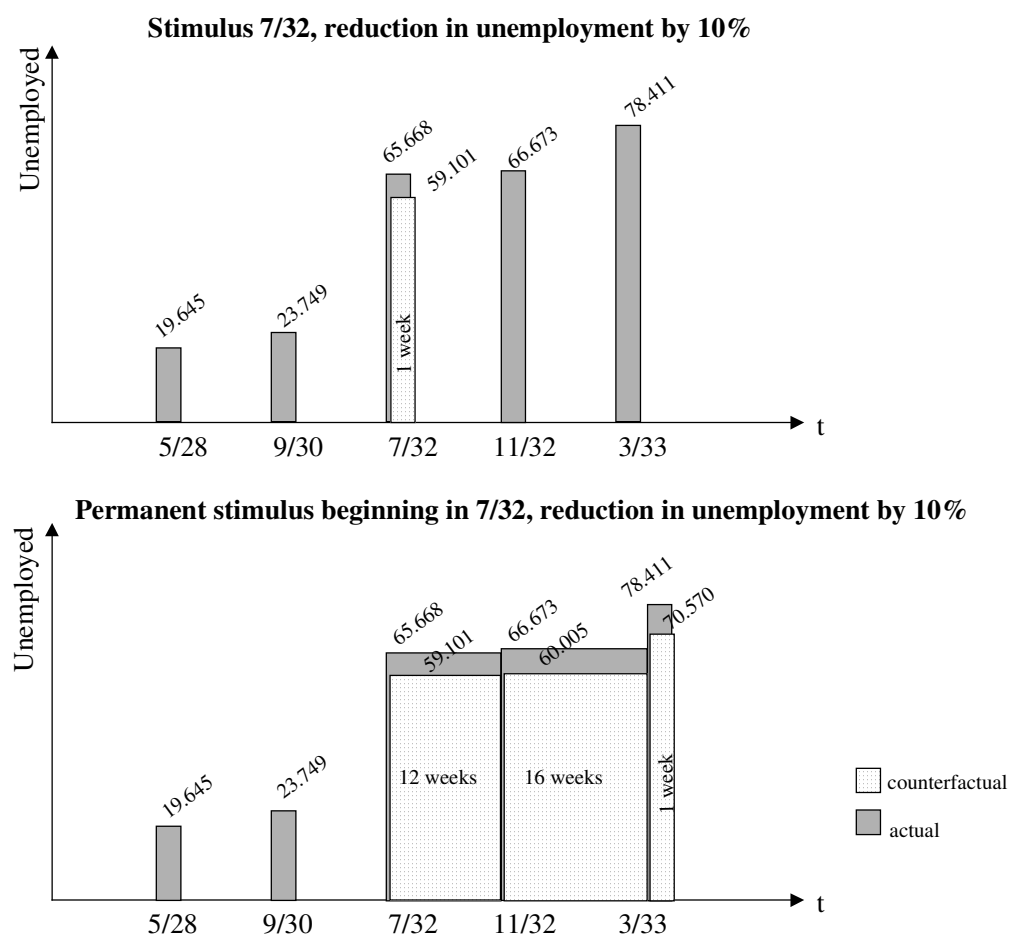
Figure 4: Difference between voting shares of the non radical parties and the radical parties SCENARIO 1

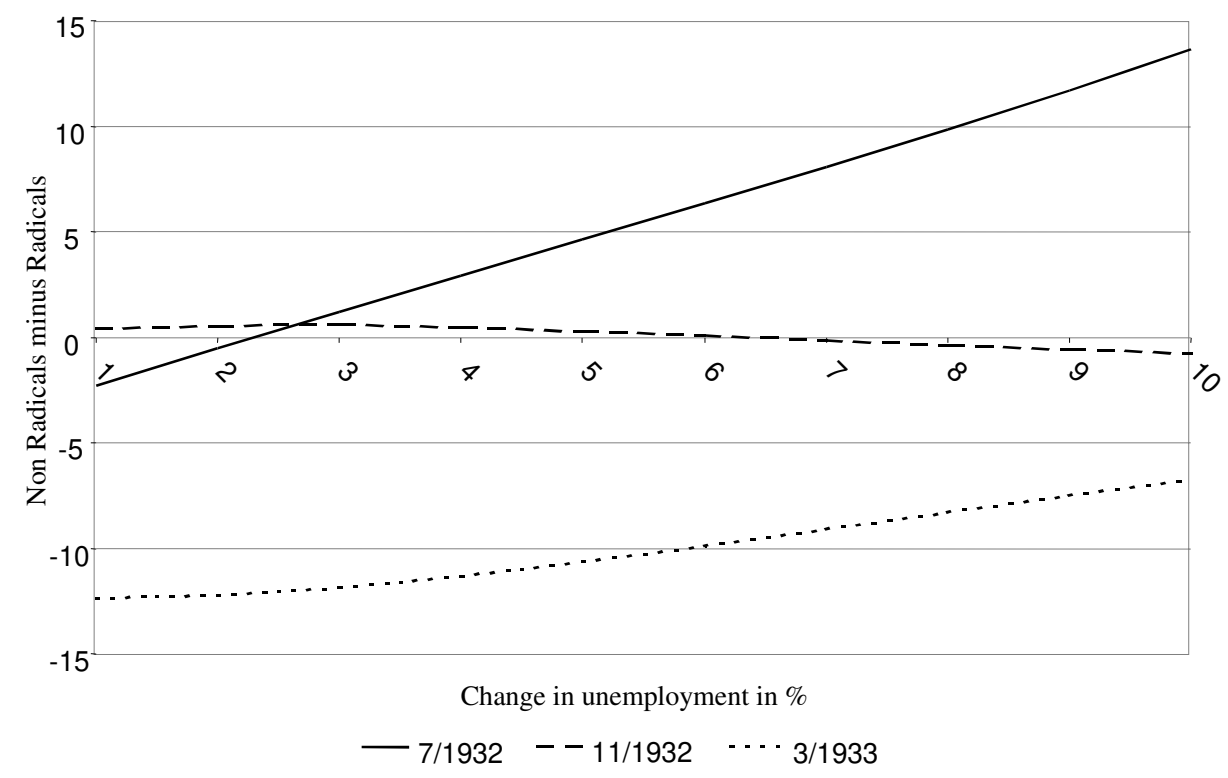

Figure 5: Difference between voting shares of the non radical parties and the radical parties SCENARIO 2a

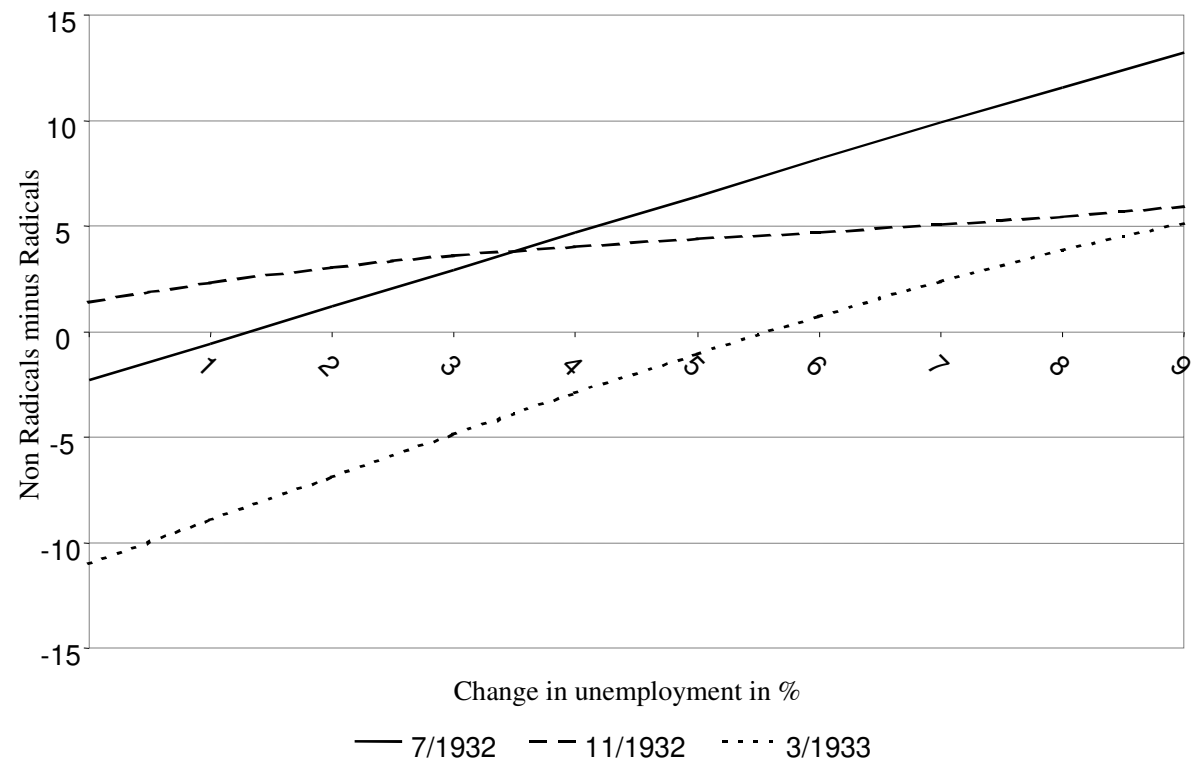


Figure 6: Difference between voting shares of SPD and NSDAP SCENARIO 2a

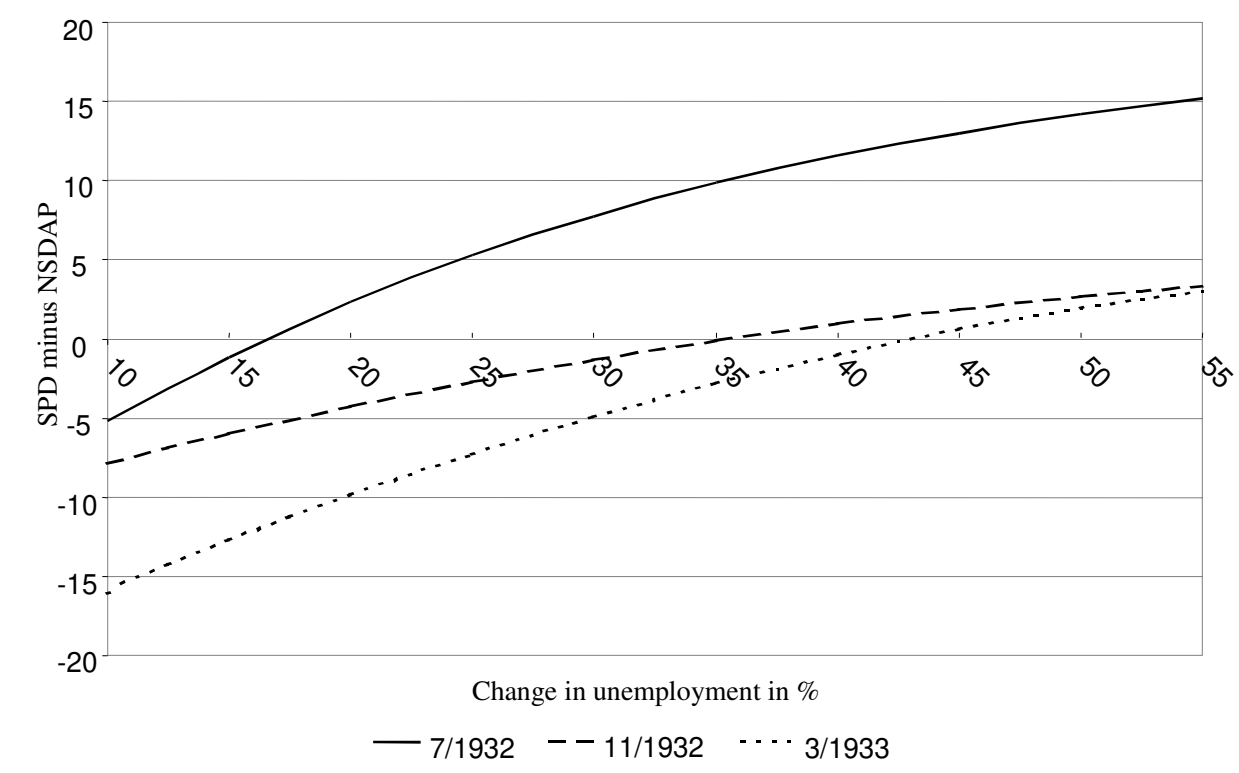

Figure 7: Difference between voting shares of SPD and NSDAP SCENARIO 2b

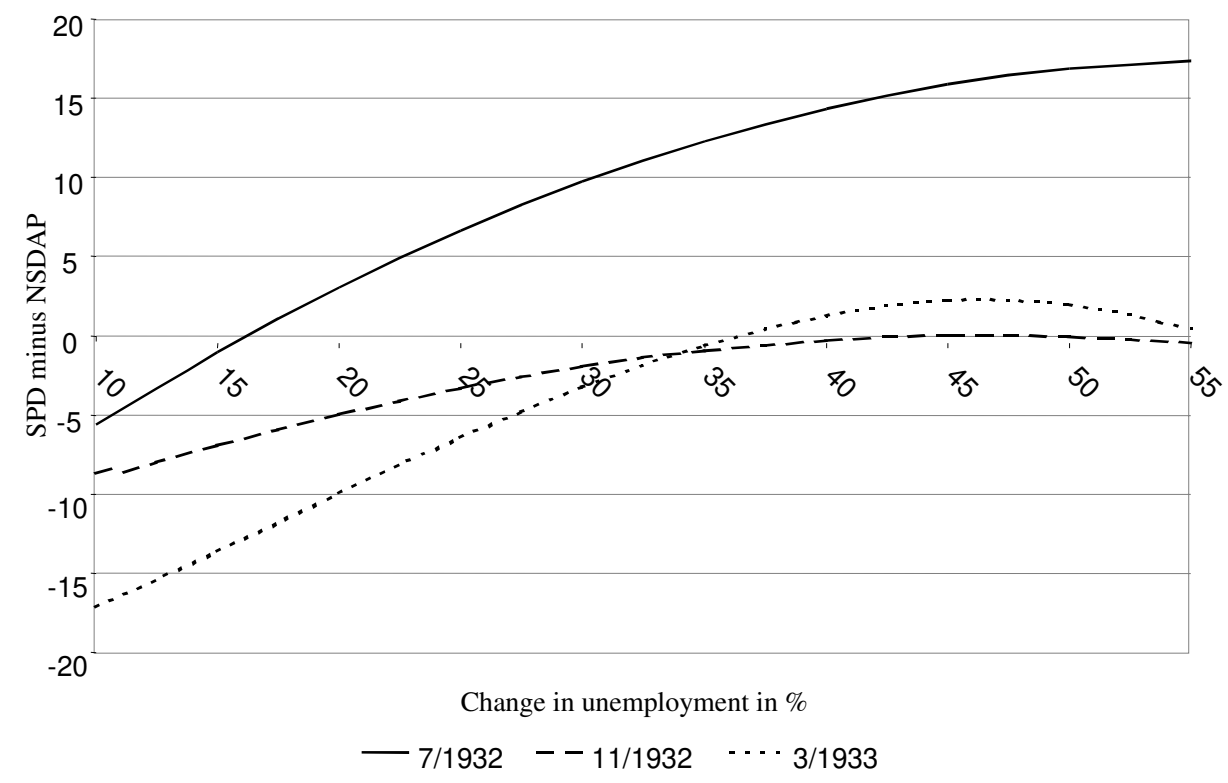


Figure 8: Transfer volumes of different scenarios (2a and 2b) in millions of Reichsmarks

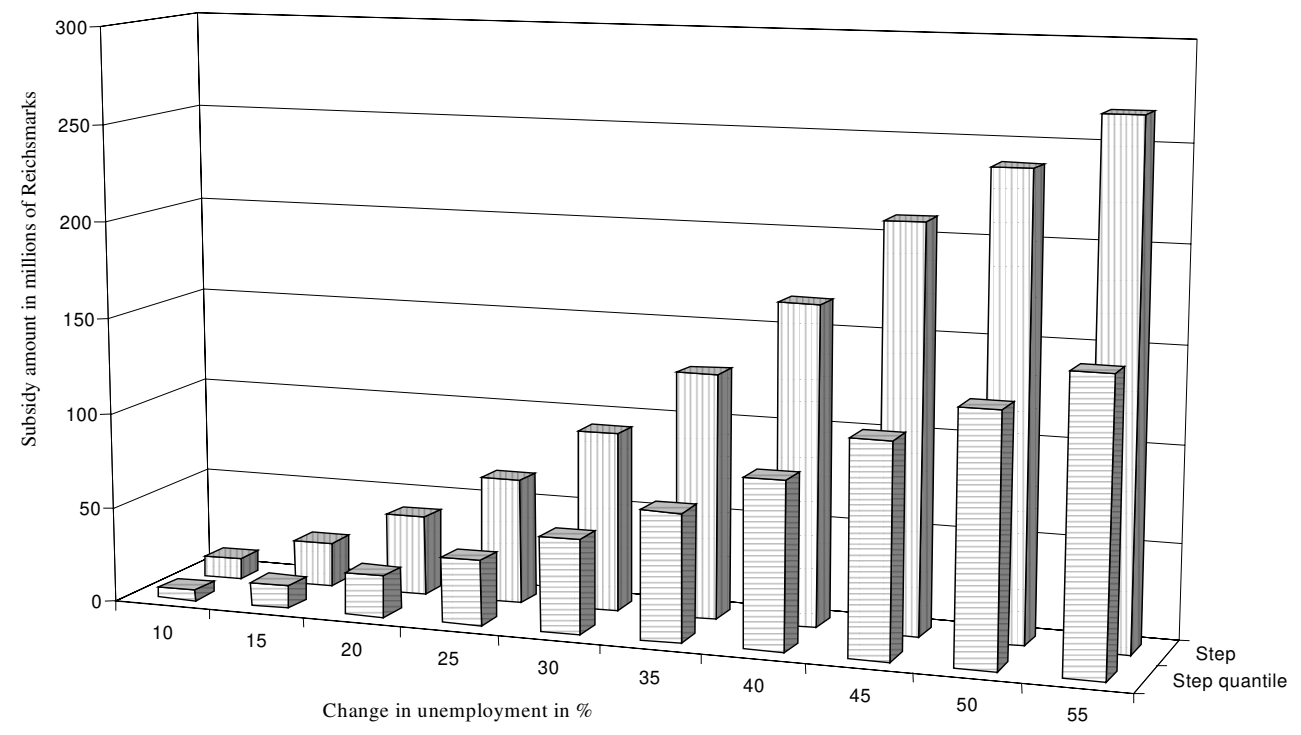




\section{References}

Anselin, L. (1988). Spatial Econometrics: Methods and Models. Dordrecht: Kluwer.

Borchardt, K. (1979). Zwangslagen und Handlungsspielräume in der großen Wirtschaftskrise der frühen dreißiger Jahre. Zur Revision des überlieferten Geschichtsbildes. Bayerische Akademie der Wissenschaften, Jahrbuch, pp. 287-325.

Bennett, R. J. (1979). Spatial Time Series: Analysis - Forecasting - Control. London: Pion Limited.

Bracher, K. D. (1955). Die Auflösung der Weimarer Republik: Eine Studie zum Problem des Machtverfalls in der Demokratie. Stuttgart: Ring-Verlag.

Broadberry, S. N. and Ritschl, A. (1995). Real Wages, Productivity, and Unemployment in Britain and Germany during the 1920s. Explorations in Economic History 32, pp. 327-49.

Corbett, D. (1991). Unemployment in Interwar Germany, 1924-1938. Harvard University, Unpublished Dissertation.

Dimsdale, N. and Horsewood, S. (1989). Real Wages and Unemployment in Britain during the 1930s. Economic Journal 99, pp. 271-92.

Eichengreen, B. and Temin, P. (2003). Counterfactual Histories of the Great Depression. in Theo Balderston (ed.), The World Economy in National Economies Between the Wars. London: Palgrave Macmillan.

Eyck, E. (1956). Geschichte der Weimarer Republik. Erlenbach-Zürich: Eugen Rentsch Verlag. Falter, J. (1987). Pitfalls in Scientific Model Building: Unemployment, the Unemployed, and the Nazi Vote 1930-1933. In: H. Wold (ed), Theoretical Empiricism: A General Rationale for Scientific Model Building. New York: Paragon House, pp. 183-200.

Ferguson, N. (ed.) (1999). Virtual History: Alternatives and Counterfactuals. New York: Basic Books.

Fishback, P., Kantor, S., and Wallis, J. (2003). Can the New Deal's Three R's Be Rehabilitated? A Program-by-Program, County-by-County Analysis. Explorations in Economic History 40, pp. 278-307.

Frey, B. and Weck, H. (1981). Hat Arbeitslosigkeit den Aufstieg des Nationalsozialismus bewirkt?. Jahrbücher für Nationalökonomie und Statistik 196, pp. 1-31. 
Flint, C. (2002). The Theoretical and Methodological Utility of Space and Spatial Statistics for Historical Studies: The Nazi Party in Geographic Context. Historical Methods 35, pp. 3242.

Henning, F.-W. (1993). Das industrialisierte Deutschland 1914 bis 1992. Paderborn: Ferdinand Schöningh.

Holtfrerich, C. L. (1997). Economic Policy Options and the End of the Weimar Republic. In Fischer (ed), The economic development of Germany since 1870. Elgar Reference Collection. Economic Development of Modern Europe since 1870, vol. 11. Cheltenham, U.K. and Lyme, N.H.: Elgar, pp. 92-127.

Institut für Konjunkturforschung. (1933). Konjunkturstatistisches Handbuch 1933. Berlin: Verlag Reimar Hobbing.

Kolb, E. (1988). Die Weimarer Republik. Munich: Oldenbourg.

Komlos, J. and Eddie, S. (1997). Cliometric Studies on German Economic History. Stuttgart: Franz Steiner Verlag. . 1999. Deutsche Kliometrie. Zeitschrift für Wirtschafts- und Sozialwissenschaften 119, pp. 293-311.

Küchler, M. (1992). The NSDAP Vote in the Weimar Republic: An Assessment of the State-ofthe-Art in View of Modern Electoral Research (1). Historical Social Research 17, pp. 2251.

Raupach, H. (1967). Der interregionale Wohlfahrtsausgleich als Problem der Politik des Deutschen Reiches. In W. Conze and H. Raupach (eds), Die Staat- und Wirtschaftskrise des Deutschen Reichs 1929/33, Stuttgart: Ernst Klett Verlag, pp.15-34.

van Riel, A. and Schram, A. (1993). Weimar Economic Decline, Nazi Economic Recovery, and the Stabilization of Political Dictatorship. Journal of Economic History 53, pp. 71-105.

Ritschl, A. (1998). Reparation Transfers, the Borchardt Hypothesis, and the Great Depression in Germany, 1929-1932: A Guided Tour for Hard-Headed Keynesians. European Review of Economic History 2, pp. 49-72. . (2002). Deutschlands Krise und Konjunktur: Binnenkonjunktur, Auslandsverschuldung und Reparationsproblem zwischen Dawes-Plan und Transfersperre 1924-1934. Berlin: Akademie-Verlag. 
Stögbauer, C. (2001a). Wählerverhalten und nationalsozialistische Machtergreifung.

Ökonomische, soziostrukturelle, räumliche Determinanten sowie kontrafaktische

Politiksimulation. St. Katharinen: Scripta Mercaturae Verlag. . (2001b). The Radicalisation of the German Electorate: Swinging to the Right and the Left in the Twilight of the Weimar Republic. European Review of Economic History 5, pp. 251-80.

Tetlock, P. E. and Belkin, A. (eds) (1996). Counterfactual thought experiments in world politics: logical, methodological, and psychological Perspectives. Princeton, N.J.: Princeton University Press.

${ }^{1}$ We would like to thank the Volkswagen Foundation for their support of this research.

${ }^{2}$ For counterfactual macroeconomic policies that might have also averted the Nazi rise to power see Eichengreen and Temin (2003).

${ }^{3}$ For other examples of this genre, see Ferguson (1998) and Tetlock and Belkin (1996) Komlos and Eddie (1997, 1999).

${ }^{4}$ If hidden unemployment is included, the number of unemployed reached 7.6 million - 38 percent of the labor force (Institut für Konjunkturforschung 1933, 15).

${ }^{5}$ For a derivation of this voting function see Stögbauer 2001a, 37ff.

${ }^{6} 830$ electoral districts times 4 parties, times 4 regressors.

${ }^{7}$ Although the DNVP (Deutschnationale Volkspartei) with which the NSDAP formed the government in January 1933 also aimed at abolishing the Weimar Republic in the long run, it was -- unlike the NSDAP -- willing to come to terms with such democratic parties as the Center Party and the DVP (Deutsche Volkspartei). For this reason, the following simulation focuses primarily on the reduction of the NSDAP's share of the vote (Stögbauer 2001a).

${ }^{8}$ Of course, it is conceivable that President Hindenburg would have sanctioned an NSDAP-led government even if these parties' share of the votes had been lower. In a functioning 
parliamentary democracy, in which the government could pass laws only with the support of a majority of members, he obviously could not have done so: to be able to govern in such a system, a party or coalition requires the backing of more than 50 percent of the votes. In the final stages of the Weimar Republic, however, minority governments were often in power. These were appointed by Hindenburg, and they governed through emergency decrees that required his approval. In making such decisions, the president was strongly influenced by his nationalist and monarchist associates, and he had a clear personal preference for at least a DNVP presence in the government. Naturally, the important role played by Hindenburg in the period immediately preceding Hitler's appointment as chancellor cannot be adequately considered here. The results of the simulation scenarios, therefore, is not conceived so as to provide an unambiguous answer to all possible scenarios pertaining to the stability of the Weimar Republic. Presidential governments could not function with a minority in the Reichstag since emergency degrees could have been repealed by a majority decision of this body. A presidential regime was dependent on the majority at least tolerating its policy, even in the absence of an active cooperation of the majority. This was the case from September 1930, with the minority cabinet of Chancellor Brüning, that was tolerated by the SPD. The presidential governments under chancellors Papen and Schleicher were, however, no longer tolerated by a majority of the Reichstag.

${ }^{9}$ A government that wanted to circumvent the Reichstag, but still remain in power would have no choice but to dissolve the Reichstag and refrain from calling new elections within the sixty-day period as specified in the constitution. However, such an open violation of the constitution would have created a state of emergency, and Hindenburg wanted to avoid that eventuality until the very end (Kolb 1988, 137). 
${ }^{10}$ Without the ability of the NSDAP and KPD to bring down a government they jointly opposed, a presidential government supported, or at least tolerated, by a majority of democratic opposition parties could have governed, as indeed the minority government under Chancellor Brüning did for a time. Certainly this would have required a presidential regime led by someone other than Papen, as his government would have been completely rejected by all parties except the DNVP. In any case, there would have been more options available for rescuing the republic if the NSDAP-KPD majority could have been prevented, and the NSDAP's chances of taking over would have been drastically reduced.

${ }^{11}$ For these purposes we are considering the DNVP in the democratic block, even if it was an opponent of the republic, but did not support its demise through a putsch.

12 The SPD was the second largest party, with 20 percent of the seats.

${ }^{13}$ Chancellor Papen resigned on November 17 and was replaced temporarily by Schleicher. The reason for Papen's resignation was that he had been unable to expand his government's narrow parliamentary base into a government of "national unity" that Hindenburg increasingly demanded (Bracher 1955, 661)

${ }^{14}$ Hindenburg agreed, but only on condition that Hitler form a majority government. Hitler was unwilling to assume power under these circumstances, as his aim was to become the leader of a presidential cabinet. He publicly rejected Hindenburg's attempts to subdue the NSDAP politically by integrating it into a DNVP-led government, stating that only he, as the leader of the strongest party, was entitled to take power (Kolb 1988, 134; Bracher 1955, 666). Hitler's "all or nothing” strategy came close to foundering, as he faced strong criticism even within his own party (particularly from Gregor Strasser). He became so desperate that he threatened suicide if he lost the confidence of his party (Eyck 1956, 553). 
${ }^{15}$ In November 1932 the combined share of votes of the democratic opposition (SPD, Center/BVP, Liberals and the splinter parties) was 41.2 percent; the share of the SPD alone was about half that amount (20.4 percent).

${ }^{16} \mathrm{We}$ are also not considering the administrative costs of such a program.

${ }^{17}$ A slack demand for goods that fell short of productive capacity also made some contribution to unemployment.

${ }^{18}$ As the unemployment rate also had a positive effect in terms of the respective shares of votes for the KPD and the democratic opposition (Table 1), restructuring unemployment to the disadvantage of these parties could also have increased the share of votes of the government.

${ }^{19}$ It is assumed that firms do not expect the subsidies or taxes on labor and therefore do not behave strategically -- for example, by temporarily laying off workers shortly before the introduction of the subsidy in order to obtain the government transfer when they are reemployed. ${ }^{20}$ Further references to estimates of labor demand elasticities for the Weimar Republic can be found in Broadberry and Ritschl (1995, 335).

${ }^{21}$ There are no further constraints imposed on the model, such as adjustment costs. The spatial distribution of $b_{i(U N)}^{N S D A P}$ indicates certain patterns, such as the clustering of electoral districts with positive values for the regression coefficients south of Munich, and the clustering of districts with negative values in southern East Prussia (Figure 1). However, these clusters do not coincide with the boundaries of the provinces, so that the counterfactual restructuring of unemployment cannot be done at the regional level (such as the reduction of unemployment in Bavaria, for instance). ${ }^{22}$ The percentages refer to the decrease in unemployment with scenario $2 \mathrm{a}$. This is also the case in scenario 1 . In other words, the policy is calibrated so as to reduce unemployment by, say $7 \%$, with scenario $2 \mathrm{a}$ (Table 4). Then we calculated how much the weekly subsidy had to be to 
accomplish this when applied for a period of 29 weeks in scenario 2a. However, with scenario 1 this weekly subsidy was applied for only one week, so that the reduction of unemployment did not reach 7\% in March 1933.

${ }^{23}$ Because scenario 1 entails a one time intervention, the reduction in the NSDAP vote pertains, in the main, to the July 1932 election depicted by the solid line in Figure 4. The impact on the subsequent election in November, 1932 is negligible.

${ }^{24}$ The change in unemployment increases in 1 percent steps, so here it is only evident that the magnitudes cross from negative to positive between $2 \%$ and $3 \%$.

${ }^{25}$ Here "effectiveness" refers to the funds required to reach a given goal.

${ }^{26}$ For the history of these issues see Borchardt (1979) Ritschl (1998) and Holtfrerich (1997).

${ }^{27}$ From the beginning of the 1920s, public money was already being made available within the East Prussian program, which lasted for several years, and from the Ostfond established to help the economically backward areas east of the Elbe. The interregional transfer took on a whole new dimension with the Osthilfe law of March 31, 1931.

${ }^{28}$ The Industrieaufbringungsumlage was introduced as the industry's contribution to the reparation payments under the Dawes Plan. The special burden on industry was discontinued under the Young Plan, but the tax was retained and turned into a Reich tax.

${ }^{29}$ The laws could have specified that only those unemployed on a certain date would have been eligible for a subsidy. 